Liudmila A. Alyabieva

Ph D., Associate Professor at Faculty of Communications, Media, and Design HSE Art and Design School, Academic Director of the Doctoral School in Arts and Design at the Higher School of Economics Research University (Moscow)

e-mail: lalyabieva@hse.ru

Moscow, Russia

ORCID0000-0001-7795-2059

ResearcherID Z-1306-2019

Irina M. Sakhno

Doctor of Philology, Professor,

Department of theory and history of culture, RUDN University, Moscow Academic Supervisor, Masters Program "Practices of Contemporary Art Faculty of Communications, Media, and Design

HSE Art and Design School e-mail: sakhno_im@pfur.ru

Moscow, Russia

ORCID0000-0002-5510-6684

ResearcherID B-2047-2016

Scopus Author ID57196349789

Tatiana E. Fadeeva

PhD in Art history, Associate Professor Faculty of Communications, Media, and Design

HSE Art and Design School

e-mail: tfadeeva@hse.ru

Moscow, Russia

ORCID0000-0002-6754-4235

ResearcherID Z-2521-2019

\title{
PRACTICE AS RESEARCH: CREATIVE AND RESEARCH PRACTICE IN THE FORMAT OF POSTGRADUATE EDUCATION
}

\begin{abstract}
Summary: The authors of the article focus on the discussion format of practical research. In recent years, practice as research has become a direction of research activity in foreign universities and an object of close attention from the Russian academic community. Representatives of various disciplines in art and the humanities convincingly argue the need for such a format of creative practice in performance, theatre, dance and contemporary art. Practice as research includes different forms and ways of representing applied and project art products. Today, a practising researcher causes controversy and discussion since the model of creative practice as a method of studying art is an innovative education-
\end{abstract}

al format. Also, the parameters of evaluating practical research, the relationship between theoretical, purely research, and creative material cause significant difficulties. The methodology based on practice and the parameters of the assessment of practice as research give rise to a lively discussion. The situation in arts and humanities teaching is complicated because practice-related research has been labelled as field research and practice-based experimentation in medicine, design and engineering for a long time. Artistic practice in contemporary art and design has recently become the object of close attention at the Graduate School of Art and Design at the Higher School of Economics since, today, 
the practical focus of visual research is the main direction in educational bachelor and master's programs. A new understanding of art as a practice and, at the same time, research can shed light on many topics, including cultural anthropology, psychology, sociology, etc. That is why we defend the idea of the interdisciplinarity of such studies in our article. Artistic practice as a field of academic research and new experience in postgraduate education is at the centre of our study. We strive to generalise the experience of European educational programs, expand the range of methodological approaches and present the author's concept. Practice and research have long been inseparable in many humanities; project workshops and representation of creative artifacts are at the heart of contemporary art and design education. Modern Russian education is just beginning to explore new territory. In this sense, our collaborative research of an innovative format is designed to analyse

\section{Introduction}

In the European education system, in the arts and humanities departments, debates and discussions about the content of the not so long ago form of practical research take place. Practice as research eliminates the existing dichotomy between theory and practice in classical education and offers an entirely new educational format for our country. Today, the fact of the influence of practice on scientific research is evident. There are many models for researching practice: practice as research, expert-led practice, and research-oriented practice. The difficulty lies in the fact that the object of attention is the study of a project in arts. It becomes an independent element of the research process and at the same time, is executed as an artistic practice. Therefore, practice as research is not a methodology; it is rather a new toolkit for studying artistic and project activities. The very term "practice as research" seems to us somewhat vague, and in the academic environment, it is positioned as a wide range of activities without delineated boundaries. Practice as research can include many characteristics in its thesaurus: this is a research process, the results of which are formalized as artistic practice, this is the practical result of research in the format of an art project, or it is a theoretical study of the achieved practical results. Such an extended interpretation of artistic practice denotes many problem areas: where does the actual artistic practice begin and end, what is the relationship between theoretical and practical results, with the help of which methodology is such an integration of research and project activity possible? It is certain that practical research, based foreign experiences and formulate the need to promote new educational technologies within the framework of graduate school. The habitus of practice as research is such that research based on practice raises the question of the forms of critical activity and content param eters of a creative artifact and documenting research materials. The posed research problem in combination with practice demonstrates the originality of research. It expands the boundaries of the research field by introducing a hybrid methodology for evaluating a creative project and critical discourse. The task of the authors of the article is to identify a debatable problem field, an alyse analytical data related to the innovative scientific field and present essential strata of the new educational format, Practice as Research.

Keywords: Practice as Research, practising researche educational formats, postgraduate studies, creative competencies, HSE

today on various creative methods, can be included in interdisciplinary creative projects that are innovative in their content. Undoubtedly, such an educational format changes our understanding of the strategies for representing modern knowledge in art and humanities, expanding the space of existing knowledge. We can say that today practical research is a powerful driver for developing a new knowledge economy and an integral part of creative industries. Practice as research in contemporary art means the approbation of scientific results in the format of an artistic project. It expands the discursive field of modern knowledge in the arts and humanities. It is a peculiar form of cultural practice and the study of broad contexts: socio-politica and artistic. In addition, practice as research is the production of new types of intellectual and cultural products in creative industries.

It is important to note the open format of practica research. It is always a discussion field for academic reflections and experimental genres of performative practices, innovative representations of research projects. The European experience of performance research in many leading European universities is well known. For example, on the website of the PARIP laboratory of the Drama Department of the University of Bristol [13], one can get acquainted with the results of practice as research and related critical activities, see the implementation of effective digita documentation systems for live performance (dance theatre, drama) - archiving the material of practica research as the most important strategy in design and research activities. Expanding the range of different forms of practice as research, modifying the usual forms of critical activity and expanding the repository's capabilities are the most important parameters for assessing the activities of such laboratories.

In July 2020, the UK Arts and Humanities Research Council, which aims to coordinate projects in science and education, developed and published a Research and Development roadmap that outlined a long-term vision to unleash the potential of science, research and innovation. Practical research in arts and humanities occupies an important place in the future strategy for the development of science. It is considered a creative tool for innovative strategies and further interaction between science and art [4]. The HSE Graduate School of Art and Design was one of the first to address the issue of the need to create a similar format of education in Russian universities. Today, a new culture of research is in demand more than ever in the format of an inclusive national approach in all countries. Russia will have to comprehend innovations in the field of education and new global challenges. Thus, the discussion of practical and applied research seems to us timely and relevant.

Reflecting on the integration of approaches to the postgraduate curriculum, we see a unique concentration of educational platforms that combine universal and professional competencies paradigms. To determine the Russian trajectory of developmen and predict the final results of innovative educational technologies, it is necessary to take into accoun the successful practices and experience of European countries while proceeding from the goal setting and direction of the trajectories of the developmen of education in Russia in the new conditions of the creative and knowledge economy. The society of innovative information technologies produces knowledge in economics and business, and the educationa sphere. Formalised education is the knowledge and experience accumulated in the learning process that will subsequently demand the educational services market The genesis of the information society is inextricably linked with the new economy of knowledge particularly with the inclusion of modern education in the international context. Today, knowledge is continuously updated, new approaches and innovations the gole of scientific and intellectual activity is increasing. In this context, creative competencies as the ability for creative self-development, developing innovative ideas and producing new approaches are particularly important. R. Ep- stein was one of the first researchers who introduced the concept of "creative competence" into scientific circulation. He characterized this phenomenon as form of adaptation to new challenges of civilization and a person's readiness for independent learning self-development and self-improvement $[9$, pp.116 140]. Of course, today, in the face of new challenges, creative competence is the ability to generate new creative ideas that will be in demand in the coming decades. Adaptability and non-standard thinking incorporation of new knowledge into practical skills and artistic activity, independence in decision-making and the ability to act, the implementation of ac cumulated experience constitute the integrativeness of knowledge and the multifactorial nature of tasks that are necessary for assessing the quality of ed ucation and professional competencies of modern university graduates.

Today, the postgraduate level of education plays the most critical role in the technologies of designing creative competencies. A legitimate question arises: how to combine standards and individual scientific platforms and make art and design education com petitive? In our opinion, "Practice as Research" as form of academic research excludes the traditional dichotomy between theory and practice. Today, the scientific and academic community continues to debate how to correctly define the emerging phe nomenon, which habitual definitions (practice-prac tice, mixed practice research, practice-research) to prioritise. All agree on one thing: research in practice-oriented graduate schools should be subordinated to practical goals. Can artistic practice be recognised as research practice? After all, any project has a conceptual basis, goals and objectives, relevance and novelty. Increasingly, foreign scientists and educators are turning to such a concept as "practical research". In 2007, the UK Arts and Humanities Research Council published a paper on practical research in the arts, design and architecture [15] which served as a basis for discussions on the issue of practice as research. The emerging definitions of practice-based and practice-led only complicated the methodology for evaluating practical research since research based on practice and research im plemented in practice are difficult to classify clearly. Undoubtedly, it is essential for us that the international community has recognised the need for a research component in practical projects.

L. Candy tries to eliminate all contradictions by reflecting on "research-based practice" and "re- 
search-led by practitioners", the main criterion of which should be the parameter of generating original ideas [7]. In any case, we are talking about a research project with different formats for its implementation. Today, practice as an integral part of the research process with documentary evidence and textual analysis represents the newest educational format. New approaches and requirements for qualification parameters indicate the need for critical reflections and an original scientific idea, which is very important for any methodology of scientific research. According to L. Candy, in the format of practical research within the framework of a doctoral degree, it is necessary to "contextualise creative work" [7], the degree of its originality and the researcher's contribution to the scientific landscape of the subject area. It is pretty evident that the space of "practical research" cannot be strictly defined, especially if we are dealing with an applied design phenomenon or the research field of contemporary art.

Practice as research, or practical research is a relevant field of professional discussion in educational and scientific discourses today. We are dealing with different blocks of theoretical and practical knowledge, with varying parameters for assessing the levels and types of practices. The gap in formulation and the lack of a unified approach are apparent One cannot but agree with Rachel Hann, a teacher of scenography at the University of Surrey, who says that the time has come to unify all approaches to the definition of "practical research" $[10, p .5]$ and that the very formula "practitioner-research$\mathrm{er}^{\prime \prime}$ is just a temporary measure. The UK was at the forefront of a system for evaluating the effectiveness of advances in practical research. This scale of differentiation, the Research Excellence Framework (REF), is an essential characteristic of recognizing lecturers' and research results effectiveness. It is the rating of schools and faculties that determines the level of funding for projects. Today, it is becoming quite apparent that practical research is expanding its space. We can talk not only about the legitimisation of the practice of artists but also about broader integrative competencies in various fields of contemporary art. Practical research is becoming multifunctional, affecting many interdisciplinary research fields. Practical research is showing its vitality today, yet there remains a "petra scandali" for academic assessment and framework documentation

The question of the forms of representation and methods of articulating the project's results and its research matrix remains a subject of debate. In what format can the methodological focus be presented? In what form should the repository of research objects (documentation, images, video formats, interdisciplinary representations, etc.) be organized using digital platforms and university sites? How importan is the project repository? An essential component of practical research, in our opinion, is not only the demonstration of all the results achieved but also the opportunity to share them with a non-academic audience. The "practicing researcher" is a new format for modern academic education, and, therefore, the bias towards this form of self-positioning by artists and designers is obvious and often criticised. Today it seems likely that a line will be drawn between "academic research" and "practical research" since the method and tools of research differ sig nificantly. It is difficult for our academic community to understand that a "practising researcher" is also a scientist. At the same time, in our opinion, it is not worth inventing new methods and ways of articulating the main content of the project; research experiments should be understandable not only to the academic but also to the non-expert audience. This conclusion is supported by the practice and re sults of the first wave of practical research despite the controversy about research ecology.

Another undoubtedly significant problem is the documentation and archiving of practical research the embodiment of the main results of a practica project in scientific articles and monographs. The future of this innovative scientific format depends on this. Today, practical research requires us to rethink the scientific methodology and expand the space of alternative educational platforms and new discursive practices. The artist and designer's own practice and research experience is an important parameter. The same can be said for performing arts departments. Today, in Europe and the Unite States, the issue of the institutional status of practical research and its inclusion in government funding programs is actively discussed. Obviously, the latest practices in contemporary art and design can be labelled only in the context of practice as research and a representative model for the approbation of scientific results. Bridging the gap between fundamental and practical research in art and design is not an easy task and requires systemic thinking and certain courage. In this sense, new formats of postgraduate studies, including PhD by Practice, seem to us the most promising.
Representation Strategies for Practice-oriented Postgraduate Programs in European Universities

Returning to the issue of various forms and strategies of representation of practice-oriented postgraduate programs, it should be noted that many of them have existed for more than a year. For example, the PhD in Practice Program [3] of the Vienna Academy of Fine Arts (Vienna), one of the leading institutions in the field of art and design, has existed for ten years (since 2010) and has already established itself as a kind of an experimental "laboratory" that flexibly responds to the demands of both creative industries and academies. The curriculum description states that contemporary artistic practices are often based on critical epistemologies, as they were developed in accordance with feminist theories, gender studies, post-Marxist and post-colonial theories, etc. The social role of contemporary art and artists who research these topics is emphasised. Emphasis is placed on the epistemological and methodological foundations and perspectives of modern art The question of how artistic practices relate to critical issues of contemporary politics and culture and business is of particular interest to the program's developers. In this regard, we can mention the exhibition held in Venice in 2017. It was organized by the participants of the HAUNTOPIA/WHAT IF PhD in Practice Program, dedicated to "ghosts" — that is, events, signs, images, practices and objects that tell about the past and "produce" reflection about a possible future. In addition, "collaboration" projects seem promising, such as, for example, the PhD Arts Program, which is the result of collaboration between the Academy of Creative and Performing Arts of Leiden University and the Royal Academy of Arts in The Hague [13]. It seems that such joint projects will make it possible to use the resource base of the participating universities more efficiently. Interesting research initiatives such as, for example S. Tunka's project, Resonances Between Dance and Gnosis, [12] appear on the page "Individual Projects" of the website of the PhDArts Program.

In addition, the Nida Doctoral School (NDS), which implements an intensive program for DA and PhD applicants in visual and performative arts, design media and architecture, and the humanities, is of great interest The program involves close cooperation with outstanding practitioners in relevant fields, reports, discussion groups, presentations of doctoral research (formal, informal, performative, experimental, etc.), peer review, group and individual consul- tations. In 2019, NDS initiatives took place at the venues of the Venice Biennale - in the Lithuanian and Research pavilions [16], etc. The format of the research pavilion itself is of great interest. Here we observe a "counter" movement - from the academy to the world of art. The research pavilion is an international project organized by Uniarts Helsink with the support of the Louise and Göran Ehrnrooth Foundation, as well as Aalto University, Valand Academy of Arts at the University of Gothenburg, University of Applied Arts Vienna and Interlab Hongik University Seoul. Within this six-year-old pavilion (a revolving project implemented for the third time at the Venice Biennale), the emphasis is placed on artistic research. The goal of the project is to attract artists and researchers from all over the world to the pavilion sites, which is thought to be a catalys for establishing cooperation in the field of artistic research and a generator of "new thinking" (a new logic of interaction between the artist and the academy). For example, the current Research Pavilion (Research Pavilion No. 3) has a modular structure consisting of six research cells - spaces for paralle processes of exhibiting, conducting, demonstrating and discussing research. One of these "modules" is called Shelters ${ }^{1}$ and is devoted to the issues of function-oriented urban planning.

Without abandoning the specifics of the "traditional" postgraduate study (writing dissertation research), Western graduate schools in art and design seek to supplement it with a natural element for creative industries - design and practical activities, the so-called "practice". Thus, conceptually significant, weighty conclusions and decisions, usually of social significance, are formed into specific projects, taking into account the context of the socio-material world and transforming this context (which expresses the practical relevance of the dissertation research).

In Russia, the format of practice-oriented postgraduate study is practically unknown. There is no a single national postgraduate school in art and design where it would be implemented. What is more there is no understanding of this type of research activity in the particular scientific literature. Today, Russian education in this area is still focused mainly on extending the traditional academic paradigm.

The project is based on research conducted over the past three
years with the Arts Research Center at Hongik University and years with the Arts Research Center at Hongik University and
the Interlab. It involves artists, curators, architects, engineers and philosophers in the research team 
Many art universities (for example, the Moscow State Surikov Academic Art Institute at the Russian Academy of Arts, the St. Petersburg State Lomonosov Academic Institute of Painting, Sculpture and Architecture and others) train specialists focused on work within the framework of academic art and do not pay enough attention to actual artistic practices, the specificity of which (in the light of modernist and postmodern transformations of art) is the understanding of the conditions of art production, as well as a wide range of issues related to the economic, political and cultural development of modern society.

On December 13, 2019, the School of Design hosted the second round table dedicated to the problems of contemporary education in the field of art and design in Russia and the world. It was the second meeting in a series of discussions initiated by the HSE Graduate School of Art and Design. Within the framework of this round table, colleagues from abroad shared their own experiences. In particular, Else Skjold, Associate Professor at the Department of Design and Sustainable Development Royal Danish Academy of Arts (Copenhagen, Denmark), presented successful research projects implemented in the PhD by Practice format at the Roya Danish Academy of Fine Arts (KADK). PhD research (DSKD) "Learning Through Materials. Developing Materials Science Teaching in Design Education" (2015) by Karen Marie Hasling was among the presented "cases". In it, the author attempts to answer how a renewed understanding of materials in design education can help students develop the skill of making informed material choices that support more sustainable solutions.

Also, within the framework of the round table new educational technologies were announced in a speech by Barbara Brownie (University of Hertfordshire, UK), who shared her experience of successful implementation of this kind of "symbiotic" projects, in which practice and theory contribute to mutual enrichment and further development of research thought. As an illustration of these ideas, a study by Dan Goodbray (completed in 2017 and defended at the University of Hertfordshire) is of particular interest. Goodbray's research focuses on digital comics and seeks to understand how key characteristics of comics affect digital mediation. In the course of his research, the author studied digital page extensions and replacements, the hybridization of video games, problems of archi- tectural space, and the integration of time-based soundtracks into the comic book structure. Since Goodbray's work is a convergence of theory and practice, he created a series of prototypes and experimental works in both the physical and digita fields as part of his practical research. They can be seen at e-merl.com. Also, Dan Goodbray did a project for a "spatial comic", placing "frames" from the comic he created in an architectural environment. Based on this project, in his research, he shows that galleries that practice this approach (placing images from comics in a specific space) rely on approaches that initially appeared in digital formats to solve problems of architectural mediality. Goodbray's research allows us to refine our understanding of the comic book as a medium. An analysis of this and other cases suggests that a new view of practice as a scientifically significant activity is currently being established in Western academic circles. Since new knowledge is obtained or partially demonstrated "in practice", the proof of the practical significance of the obtained conceptual conclusions also occurs not only within the framework of theory but also in the space of practical research, which contributes to their verification.

Criteria for Assessing the Practical Significance

\section{of Projects: Preliminary Results}

In issues related to the institutionalization of practice-oriented postgraduate study programs, the effective criteria for evaluating the project itself are the most debated. It is partly due to the difference in approaches (academic theory tends more towards descriptive-analytical approaches and methods, whil practice - towards creative-activity, aimed at solving a specific problem). The combination of these approaches to actualize their effectiveness seem to be the most effective strategy. Thus, discussions about design thinking and design methodology in relation to science can be found in the works of many researchers. Robert McKim, an artist and enginee the author of the book Experiments in Visual Think ing (1973), is among the most interesting. Gerbe Simon formulated the very concept of "design think"ng" in his book The Sciences of the Artificial (1969) [2]. In his article "Design Ways to Know" [1], Nige Cross identifies the unique characteristics of design thinking finding it helpful to integrate it into the education system and the broader academic context. Finally, Brian Lawson did an in-depth study of the characteristics of design thinking and academic thinking. In empirical studies of three-dimensiona problem solving using two groups of students ("practitioners" and "scientists"), he found that "practitioners" used cognitive strategies focused on solving a problem ("synthesis"), and "scientists" used problem-oriented strategies ("analysis") [11]. The idea of combining both within the framework of a systematic approach is now being heard more and more of ten, and not only among designers/artists or in the academic environment but also in the field of business. For example, there is the DesignLondon Educational and Research Center (Great Britain), which combines three of the most influential schools in Britain in their field: the Design Department of the Royal College of Art, the Engineering Department at Imperial College and the Business Department from the Imperial College Business School. Among other significant projects in this area is the RED company (an initiative to transform the public sector and public services (Design Council, British Design Council); the goal is "the introduction of design innovations to improve the standard and quality of life", "the implementation of design in the social and economic sphere to address critical issues") [8], as well as the IDEO, international design consulting organisation. In addition to design projects related to society's problems and the economy, there are similar initiatives in art. For example, it is "social art" area, also associated with incorporating the artist into the social and economic sphere to transform it.

It seems logical that the project component of practice-oriented postgraduate project should be inscribed in the logic of the corresponding problem field, and educational institutions are obliged to present options for solving the problems posed. At the same time, the project component must exist within the framework of a strong theoretical structure of a high academic level. As one example of the existing "codification" of criteria for evaluating such studies, we can mention the joint PhD Arts program (the result of a collaboration between the Academy of Creative and Performative Arts of Leiden University and the Royal Academy of Arts in The Hague), which was discussed above. The program's website provides essential concepts, formulates criteria for evaluating practice-based research, and gives its definition: "Practice-based research applied to creative specialities is understood as research conducted in the field of artistic practices and design methods and with their application (for example, in areas such as visual arts, audiovisual art, design, interior design, mixed forms and interdisciplinary fields); at the same time, the practical activity and analyt ical work of the researcher are inextricably linked with the research topic, its process and results. an applicant is applying for a doctorate, they must demonstrate a high level of creative skill, originality and skills so that their research can be assessed as an important and innovative contribution to science, philosophy of art and creative practice" [13].

Similar "codifications" of requirements and criteria for evaluating the text component and project activities exist in all practice-oriented postgraduate programs. Differences can be in the number of experts involved in project evaluation, in the requirements for the volume of the text and for the documentation accompanying the project, etc. In 2006, Linda Candy made a presentation and wrote a guide article "Practice-Based Research: A Guide" $[6,7]$, in which she attempted to reflect the specifics of this issue; later, this "guide" was developed in her 2018 article "Practice-based Research in the Creative Arts: Foundations and Futures from the Fron Line" [5, pp.63-69], which she wrote with Ernest Edmondson. The article contains descriptions of a large number of "cases"; analysing one, Candy and Edmondson summarize: "The central results were embodied in artworks that facilitated and encouraged emergent thinking in members of the participating audience. It was necessary to demonstrate that this was, in fact, the case, and so, as well as delivering the research results in both text and documented artifact forms, the results of evaluations of participant responses were reported. Thus, the argumen that was claimed was supported by evidence gathered in a relatively conventional way. It is an example of practice-based research in which art making is central but in which evidence-based conclusions are provided." [5, pp.63-69].

Finally, the research evaluation and certification criteria at the Royal Danish Academy of Fine Arts $(\mathrm{KADK})^{2}$ serve as a valid "working model":

"Clarity: The criterion refers to the aesthetic aspect of the work. It is necessary to assess how the work is separated from the context and conditions of creation. In accordance with this criterion, the work's aesthetic effect and the artistic language chosen by the author (artistic level) are discussed.

Density: The criterion refers to the technical component of the work. It is essential to understand

Since the wording is periodically revised, the version on the in the text of this article. 
that the appearance of the work contains the effect and how the connection between the elements determines the intensity of the impact. This criterion evaluates how material properties, functions and concepts are combined in new contexts (technical level).

Depth: The criterion refers to the semantic component of the work. It is important to determine the depth of the relationship between the work and the formation of meaning in culture and society. According to this criterion, the work is compared to the class of works that have demonstrated the relevance of the topic development, and its contribution is discussed (contextual/theoretical level).

Expert judgment: a qualified practitioner + a qualified researcher in the given field" [17].

Thus, based on the analysis of the programs of practice-oriented postgraduate studies, the following can be distinguished among the main criteria for evaluating the practical component of the dissertation project:

- justification of the project's relevance (description of the boundaries of the problem field, problem statement, goal formulation; does the proposed project solve the problems posed or offer solutions to the problems posed?

- originality and novelty (the project must be original and not have complete analogues);

- presentation of the project; it is evaluated by n expert/experts (leading experts in the relevant problem area);

- knowledge of methodology, including design methodology (e. g., artistic research, practice as research, design methodology); it is evaluated by an expert/experts (leading experts in the relevant problem area):

- the presence of a qualified team implementing the project, the logic of phased planning, other conditions conducive to successful implementation the achieved results of implementation (for example, the presence of artifacts (works), the fact of an exhibition, performance, etc.);

- the social significance of the project (for ex ample, appreciation from the expert community, press reviews, etc.); an expert assessment of leading experts in this field is possible; the project's investment attractiveness can be taken into account

\section{Conclusion}

Now, there is a process of "rapprochement" between the academic community and the community of "practitioners" - artists and designers since on the one hand, scientists are interested in putting their developments into practice. On the other hand artists and designers need to differentiate and conceptualise their subject fields. It is because the processes in production, design, and partly in art began to change. There is a transition from creating artifacts/artifact corpus to designing intangible things it can be a service, strategy, "atmosphere", etc. This situation has led to the fact that new formats of the interaction of "theory and practice" began to appear in the space of academic educational programs. It can also be seen at the level of higher education we are talking about the format of practice-oriented postgraduate study ("PhD by Practice", "Art PhD" h" "practice-led research", etc). Within the framework of this article, we have made an attempt to reflect the specifics of this format, turned to the experience of foreign countrie where this format is gaining more and more popularity, raised the problems (primarily methodological) associated with the integration of this format into the space of academic knowledge, reflected the controversial nature of such a concept as "Practice as Research", and ways of developing this educational format. There is still an intense discussion on the status of "practice" as an educational format. It seems that today the search for new forms of interaction between the academic community and the community of "practitioners", and the "refinement" of existing formats is an urgent task, the solution of which will contribute to the development of socia and cultural initiatives and the formation of a creative community dominated by art. Summarising what has been said, it is safe to say that PhD-level postgraduate programs discussed at the Graduate School of Art and Design at the Higher Schoo of Economics are an alternative form of education during which students can not only expand theoretical knowledge, conduct interdisciplinary research but also represent project forms, demonstrating the skills and competencies acquired in the field of conpractical research, making it possible to update the approach to practice as research and incorporat methodological tools into representative forms of project approbation. Practice-oriented postgraduate programs for the Russian education system are an innovative format that requires understanding and choosing one's own educational strategy related to the specifics of multilevel and multidisciplinary education in Russia.

REFERENCES:

1. Cross, N. 1982. Designerly Ways of Knowing, [Online resource]. - URL: http://larossa.co/cross_1982 designerlywaysofknowing.pdf (date of access: 05.07.2021).

2. Simon, G. 1969. The Science of the Artificial, Moscow: Mir

3. "Art \& Education", PhD in Practice, Academy of Fine Arts Vienna [Online resource]. URL: https://www. artandeducation.net/announcements/109662/phd-inpractice-academy-of-fine-arts-vienna/ (date of access: 05.07.2021)

4. "Arts and Humanities Research Council" [Online resource].—URL: https://ahrc.ukri.org/ (date of access: 05.07.2021).

5. Candy, L., Edmonds, E. 2018. "Practice-based Research in the Creative Arts: Foundations and Futures from the Front Line", LEONARDO, vol. 51, no. 1

6. Candy, L. "Theory and Practice in Creative Practitione Research." Unpublished paper based on Keynote Talk to DESIRE2011 conference Eindhoven NL. [Online resource]. URL: https://www.academia.edu/10331703/ Theory_and_Practice_in_Creative_Practitioner

Research/ (date of access: 05.07.2021)

7. Candy, L. "Practice Based Research: A Guide." CCS Report: 2006-V1.0 November [Online resource]._URL https://www.researchgate.net/publication/257944497/ (date of access: 05.07.2021).

8. "Design Council" [Online resource]. - URL: https:// "www. designcouncilorg uk/ (date of access: 05.07 2021).

. Epstein, R. (2005). "Generativity Theory and Creativity", M. A. Runco \& R. S. Albert (Eds.), Theories of creativity (Rev. ed.). Cresskill, NJ: Hampton Press, 2005.
10. "Interview between the JAWS editorial team and D Rachel Hann", Journal of Arts Writing by Students, vol. 5, No. 1, 1 March 2019

11. Lawson, B. 2005. "How Designers Think - The Desig Process Demystified", University Press, Cambridge

12. PhDArts / Individual Projects / Resonances between Dance and Gnosis [Online resource].— URL: https:// www.phdarts.eu/ResonancesbetweenDanceandGnos is/ (date of access: 05.07.2021).

3. PhDArts, an international doctorate program in art and design, is a collaboration between Leiden University Academy of Creative and Performing Arts and the Royal Academy of Art (KABK) in The Hague [Online resource]._URL: https://www.phdarts.eu/Admission/ Requirements/ (date of access: 05.07.2021).

14. "Practice as Research in Performance: 2001-2006" [Online resource]._ URL: http://www.bristol.ac.uk/ parip/ (date of access: 05.07.2021).

15. Rust, C., Mottram J., Till, J. 2007. AHRC Research Review. Practice-Led Research in Art, Design and Architecture. [Online resource].— URL: http://www.ahrb.ac.uk/ research/grant/guide.htm / (date of access: 05.07.2021).

6. Research Pavilion \# 3 Venice 2019 [Online resource].URL: http://www.researchpavilion.fi/ (date of access: 05.07.2021).

17. The Royal Danish Academy of Fine Arts Schools of Architecture, Design and Conservation, Research and artistic research at KADK [Online resource].- URL: https://kadk.dk/en/research-and-artistic-researchkadk/ (date of access: 05 07.2021) 
Людмила Анатольевна Алябьева кандидат филологических наук, доцент Факультета коммуникаций, медиа и дизайна Ниу вшэ, Академический директор Аспирантской школы по искусству и дизайну e-mail: lalyabieva@hse.ru Москва, Россия

ORCID0000-0001-7795-2059

ResearcherID Z-1306-2019

Ирина Михайловна Сахно доктор филологических наук, профессор кафедры теории и истории культуры RUDN UNIVERSITY, Академический руководитель магистерской программы «Практики современного искусства» Факультета коммуникаций, медиа и дизайна, Школы дизайна НИУ вШэ e-mail:sakhno_im@pfur.ru Москва, Россия ORCID0000-0002-5510-6684 ResearcherID B-2047-2016 Scopus Author ID57196349789

Татьяна Евгеньева Фадеева кандидат искусствоведения, доцент Факультета коммуникаций, медиа и дизайна НИУ вШЭ e-mail: tfadeeva@hse.ru Москва, Россия ORCID0000-0002-6754-4235 ResearcherID Z-2521-2019

DOI: 10.36340/2071-6818-2021-17-4-91-109

\section{"PRACTICE AS RESEARCH": ИССЛЕДОВАТЕЛЬСКАЯ И ТВОРЧЕСКАЯ ПРАКТИКА В ФОРМАТЕ ПОСТДИПЛОМНОГО ОБУЧЕНИЯ}

Аннотация: В центре внимания авторов статьи дискуссионный формат практических исследований: "Practice as Research". В последние годы практика как исследо бар

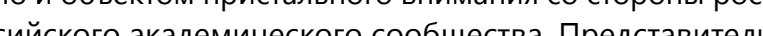
сийско о академическо о сообществ Представители разлиных дисциплин в области искусства и ууманиТарных наук убедительно доказывают необходимость подбного формата творческой практики в сфере перформанса, театра, танца и современного искусства. Практика как исследование включает в себя разные формы и способы репрезентации прикладных и проектных художественных продуктов. Фитура практикующег исследователя вызывает сегодня споры и дискуссии потому что модель творческой практики как метод из учения искусства - инновационный образовательный формат. Большие трудности вызывают и параметры оценки практического исследования, соотношение те- оретического, чисто исследовательского, и творческого материала. Живое обсуждение вызывает как методоогия основанна на практике таки собствено параметры оцени практики как исследования. Ситуацив препо

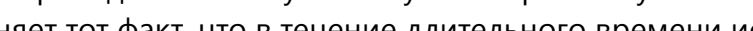
с солер

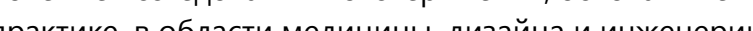

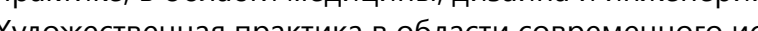
Художеская пракика в области современного искуссва и дизайна в последнее время стала объектом пристального внимания в Аспирантской школе по искуству и дизайну НИУ ВШЭ, потому что практический фокус визуальных исследований- основной трек сегодня в образовательных бакалаврских и магистерских программах. Новое понимание искусства как практики и одновременно исследования может пролить све на многие темы, включая культурную антропологию,

своей статье отстаиваем идею междисциплинарности подобных исследований. Художественная практика как область академических исследований и новый опыт постдипломного образования находится в центре наших исследовательских рефлексий. Мы стремимс обобщить опыт европейских образовательных программ, расширить диапазон методологических подходов и представить авторскую концепцию. Практика и исследование давно неразделимы во многих гуманитарных науках, проектные семинары и регрезентани творческих артефактов - суть образования в обаци современного искусства и дизайна. Современное российское образование только начинает осваивать ной територио, $n$ в этом синсле наше коллективно исследование иннованионного формата призвано проинализироват зарубежнй орыт и сформулировать необходимость продвижения новых образоватед

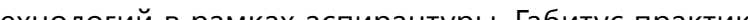

\section{Введение}

В системе европейского образования на факультетах искусства и гуманитарных наук ведутся споры и дискуссии о содержании зародившегося не так давно формата практических исследований. "Practice as Research" устраняет сложившуюся дихотомию между теорией и практикой в классическом образовании и предлагает совершенно новый для нашей страны образовательный формат. Сегодня факт влияния практики на научное исследование очевиден. Существует множество моделей исследования практики: практика как исследование; практика под руководством практика; практика, ориентированная на исследование. Сложность состоит в том, что объектом внимания является исследование проекта в области искусств, который становится самостоятельным элементом исследовательского процесса, оформленным при этом как художественная практика. Поэтому практика как исследование не является методологией, скорее, это новый инструментарий исследования художественно-проектной деятельности. Сам термин «практика как исследование» представляется нам достаточно размытым, и в академической среде позиционируется как широкий спектр деятельности без очерченных границ. Практика как исследование может включать в свой тезаурус множество характери стик: это и исследовательский процесс, результаты которого оформлены как художественная практика, это и практический результат исследования в формате арт-проекта, или это теорети ческое исследование достигнутых практических результатов. Такое расширенное толкование ху- как исследования таков, что в исследованиях, основанных на практике, ставится вопрос о формах критической деятельности и содержательных параметрах творческого артефакта, о документировании матери алов исследования. Поставленная исследовательская проблема в сочетании с практикой демонстрирует оригинальность исследования и расширяет границн исследовательского поля посредством введения гибридной методологии оценки творческого проекта и критиче ского дискурса. Задача авторов статьи - обозначит дискуссионное проблемное поле, проанализироват аналитические данные, связанные с инновачиовны научным полем и представить важные страты нового образов Ключевне cлова: "Practice as Research", nparmuky-

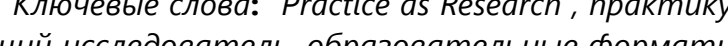
аспирантура, креати, образовательные формап

дожественной практики обозначает множество проблемных зон: где начинается и заканчивается собственно художественная практика, в каком соотношении находятся теоретические и практические результаты, с помощью какой методологии возможна подобная интеграция исследования и проектной деятельности? Ясно одно, что практические исследования, опираясь сегодня на различные творческие методы, могут быть включены в междисциплинарные творческие проекты, инновационные по своему содержанию. Без сомнения, подобный образовательный формат меняе наши представления о стратегиях репрезентаци современных знаний в области искусства и гуманитарных наук, расширяя пространство существующих знаний. Можно сказать, что практические исследования сегодня - являются мощным драй вером развития новой экономики знаний и составной частью креативных индустрий. Практика как исследование в современном искусстве озна чает не только апробацию научных результатов в формате художественного проекта, но и расширяет дискурсивное поле современных знаний в области искусств и гуманитарных наук. Это своеобразная форма культурной практики и ис следование широких контекстов: социально-политических и художественных. Это и производство новых видов интеллектуальных и культурных продуктов в сфере творческих индустрий.

Важно отметить открытый формат практических исследований. Это всегда дискуссионно поле для академических рефлексий и экспери ментальные жанры перформативных практик, инновационные репрезентации исследователь- 
ских проектов. Хорошо известен европейский опыт исследования перформанса во многих ведущих европейских университетах. Например, на сайте лаборатории PARIP Факультета драмы Бри стольского [13] университета можно ознакомиться с результатами практики как исследования и свя занной с ней критической деятельностью, увидеть внедрение эффективных систем цифровой документации для живого исполнения (танец, театр, драма) - архивирование материала практических исследований как важнейшей стратегии в проектно-исследовательской деятельности. Важнейшими параметрами оценки деятельности подобных лабораторий являются расширение диапазона разных форм практики как исследования, модификация привычных форм критической деятельности и расширение возможностей репозитория.

В июле 2020 года Совет по исследованиям в области искусств и гуманитарных наук Великобритании, цель которого - координация проектов в области науки и образования, разработал и опубликовал дорожную карту «Исследования и разработки», в которой изложено долгосрочное видение, направленное на раскрытие потенциала науки, исследований и инноваций. В будущей стратегии развития науки практические исследования в области искусств и гуманитарных наук занимают важное место и рассматриваются как креативный инструмент инновационных стратегий и дальнейшего взаимодействия науки и искусства [4]. Аспирантская школа по искусству и дизайну ВШЭ одна из первых обратилась к вопросу о необходимости создания подобного формата образования в российских вузах. Новая культура исследований сегодня как никогда востребована в формате инклюзивного национального подхода во всех странах. России предстоит осмыслить инновации в сфере образования и новые глобальные вызовы, в силу чего обсуждение практических и прикладных исследований кажется нам своевременным и актуальным.

Формат практических исследований

pro \& contra

Размышляя об интеграции подходов к аспирантской программе обучения, мы видим уникальную концентрацию образовательных платформ, которая сочетает парадигмы универсальных и профессиональных компетенций. Для того, чтобы определить российскую траекторию развития и прогнозировать конечные результаты инно- вационных образовательных технологий, нужно учитывать успешные реализуемые практики и опыт европейских стран, при этом исходить из целеполагания и направленности тракторий развития образования в России в новых условиях креативной экономики и экономики знаний. Общество инновационных информационных технологий продуцирует знания не только в экономике и бизнесе, но и в образовательной сфере. Формализованное образование - это тот накопленный в процессе обучения багаж знаний и опыта, который будет впоследствии востребован на рынке образовательных услуг. Генезис информацион ного общества неразрывно связан с новой экономикой знания, и, в частности, с включение современного образования в международный контекст. Сегодня знания непрерывно обновля ются, генерируются новые подходы и инновации возрастает роль научной и интеллектуальной де ятельности. В этом контексте особенное значение приобретают креативные компетенции как способность к творческому саморазвитию, генерированию инновационных идей и продуцированию новых подходов. Одним из первых исследовате лей, кто ввёл в научный оборот понятие «креативная компетентность», был Р. Эпстайн, который охарактеризовал этот феномен как форму адаптации к новым вызовам цивилизации и готовност человека к самостоятельному обучению, самораз витию и самосовершенствованию [9, р. 116-140] Безусловно, креативная компетентность сегодня в условиях новых вызовов, - это способност к производству новых творческих идей, которые будут востребованы в ближайшие десятилетия. Адаптивность и нестандартность мышления, инкорпорирование новых знаний в практические навыки и художественную деятельность, самостоятельность в принятии решений и способность к действию, реализация накопленного опыта это интегративность знаний и многофакторность задач, которые необходимы в оценке качества образования современных выпускников вузов.

В технологиях проектирования креативных компетенций важнейшую роль играет сегодня аспирантская ступень обучения. Возникает вполне правомерный вопрос, как совместить стандарть и индивидуальные научные платформы, как сделать образование в области искусства и дизайн конкурентоспособным? На наш взгляд, "Practice as Research" как форма академического иссле- дования исключает традиционную дихотомию между теорией и практикой. Сегодня в научном и академическом сообществе продолжаются споры о том, как корректнее определить зарождающийся феномен, какие привычные дефиниции (практика - практика, смешанная практика исследования, практика-исследование) сделать приоритетными. Все сходятся в одном: исследования В практико-ориентированных аспирантурах должны быть подчинены практическим целям. Может ли художественная практика быть признана исследовательской? Ведь любой проект имеет концептуальную основу, цели и задачи, актуальность и новизну. Все чаще зарубежные учёные и педагоги обращаются к такому понятию, как «практические исследования». Совет по исследованиям в области искусств и гуманитарных наук Великобритании опубликовал в 2007 году доклад, посвященный практическим исследованиям в области искусства, дизайна и архитектуры [15], что послужило основой для дискуссий по проблеме практики как исследования. Появившиеся дефиниции practice-based $и$ practice-led лишь усложнили методологию оценки практических исследований, потому что исследования, основанные на практике, и исследования, реализуемые на практике, трудно поддаются чёткой классификации. Несомненно, для нас более важным является то, что международным сообществом был признан факт необходимости исследовательской компоненты в практических проектах.

Л. Кэнди пытается аннулировать все противоречия, размышляя об «исследованиях на основе практики» и «исследованиях под руководством практиков», основным критерием которых должен стать параметр генерирования оригинальных идей [7]. В любом случае речь идёт об исследовательском проекте с разными форматами его реализации. Практика как неотъемлемая часть исследовательского процесса с документальным подтверждением и текстологическим анализом представляет сегодня новейший образовательный формат. Новые подходы и требования к квалификационным параметрам свидетельствуют о необходимости критических рефлексий и оригинальной научной идеи, что очень важно для любой методологии научного исследования. В формате практических исследований в рамках докторской степени, по мысли Л. Кэнди, обязательна «контекстуализация творческой работы» [7], степень её оригинальности и вклад учёного в научный ландшафт предметной области. Совер шенно очевидно, что пространство «практических исследований» невозможно строго обозначить, тем более, если мы имеем дело с прикладным феноменом дизайна или исследовательским полем современного искусства.

Практика как исследование, или практические исследования,-это актуальное поле професси ональных дискуссий сегодня в образовательных и научных дискурсах. Мы имеем дело с различными блоками теоретических и практических знаний, с разными параметрами оценки уровней и видов практик, и разрыв в формулировках и отсутствие единого подхода очевидны. Нельзя не согласитьта Сюррея Рейчел Ханн, которая говорит о том что пришло время унифицировать все подходы к определению «практических исследований $[10$, р. 5], и что сама формула «практик-исследо ватель» - это всего лишь временная мера. Великобритания стояла у истоков системы оценки эффективности достижений в области практических исследований. Эта шкала дифференциаций Research Excellence Framework (REF) - является важнейшей характеристикой признания эффективности лекторов и результатов исследования. Именно рейтинг школ и факультетов определяет уровень финансирования проектов. Сегодня совершенно очевидным становится тот факт, что практические исследования расширяют своё пространство, и мы можем говорить не только о легитимизации практики художников, но и о боле широких интегративных компетенциях в разных областях современного искусства. Практические исследования становятся полифункциональными они затрагивают многие междисциплинарные исследовательские поля. Практические исследования сегодня демонстрируют свою жизнеспособность, и всё же остаются «petra scandali» дл академической оценки и рамочной документации

Остаётся дискуссионным вопрос о формах репрезентации и способах артикуляции результатов проекта и его исследовательской матриць. В каком формате может быть представлен методологический фокус? В какой форме должно быть организовано хранилище объектов исследования (документация, изображения, видеоформаты, междисциплинарные репрезентации и т.д.) с использованием цифровых платформ и университетских сайтов? Насколько необходим репозиторий проекта? Важной составляю- 
щей практического исследования, на наш взгляд, является не только демонстрация всех достигнутых результатов, но и возможность поделиться ими с неакадемической аудиторией. «Практи кующий исследователь» - новый формат для современного академического образования, и потому предвзятость к этой форме самопозиционирования художников и дизайнеров очевидна и часто подвергается критике Сегодня кажется вероятным, что между «академическим исследованием» и «практическим исследованием» будет проведена граница, ибо метод и инструментарий исследования существенно отличаются. Трудно смириться нашему академическому сообществу С тем, что «практикуощий исследователье- Тоже учёный. При этом, на наш взгляд, не стоит изобретать новые методы и способы артикуляции основного содержания проекта, исследовательские эксперименты должны быть понятны не только академической, но и неэкспертной аудитории. В пользу этого вывода говорит практика и результаты первой волны практических исследований несмотря на возникший спор об исследовательской экологии.

Ещё одна несомненно важная проблема - это документирование и архивирование практических исследований, воплощение основных результатов практического проекта в научных статьях и монографиях. От этого зависит будущее этого инновационного научного формата. Практические исследования сегодня требуют от нас переосмысления не только научной методологии но и расширения пространства альтернативных образовательных платформ и новых дискурсивных практик. Важным параметром становится собственный практический и исследовательский опыт художника и дизайнера. То же самое можно сказать и о факультетах исполнительских искусств. Сегодня в Европе и США активно обсуждается вопрос об институциональном статусе практи ческих исследований и их включении в государственные программы финансирования. Очевидно, что новейшие практики в современном искусстве и дизайне могут быть маркированы только в контексте практики как исследования и репрезентативной модели апробации научных результатов. Преодолеть разрыв между фундаментальными и практическими исследованиями в области искусства и дизайна - задача непростая и требуе системного мышления и определённой смелости и в этом смысле новые форматы аспирантуры, включая PhD by Practice, кажутся нам наиболее перспективными

Стратегии репрезентации практико-ориентированных аспирантских программ в европейских вузах

Возвращаясь к вопросу о различных формах и стратегиях репрезентации практико-ориенти рованных аспирантских программ, необходи мо отметить, что многие из них существуют уже не первый год. Например, программа «PhD in Practice» [3] Венской академии искусств (Academy of Fine Arts, Vienna), одной из ведущих инсти туций в сфере искусства и дизайна, существует 10 лет (с 2010 года) и уже успела зарекомендотальной «лаборатории», гибко реагирующей на запросы и креативных индустрий, и академий В описании программы говорится, что современные художественные практики зачастую ос нованы на критических эпистемологиях, так как они были разработаны в соответствии с гендерными исследованиями, феминистскими, постмарксистскими и постколониальными теориям и т.д. Подчёркивается социальная роль современного искусства и художников, которые занимаются исследованиями этих тем. Акцент делается на эпистемологических и методологических основах и перспективах современного искусства, особый интерес для разработчиков программы представляет вопрос о том, как художественные практики связаны с важными вопросами современной политики и культуры, а также с бизнесом. В связи с этим можно упомянуть состоявшуюс в 2017 году в Венеции выставку участников программы «PhD in Practice» «HAUNTOPIA / WHAT IF», посвящённую «призракам» - Т. е. событиям, знакам, образам, практикам и предметам, которые рассказывают о прошлом и «продуцируют рефлексию о возможном будущем. Кроме этого перспективными представляются «коллаборационные» проекты - такие как, например, программа «PhDArts», которая является результатом сотрудничества между Академией креативных и перформативных искусств Лейденского универ ситета и Королевской академией искусств в Гааг [13]. Представляется, что подобные совместные проекты позволят более эффективно использовать ресурсную базу университетов-участников На странице «Индивидуальные проекты» сай та программы «PhDArts» фигурируют любопыт ные исследовательские инициативы, такие как например, проект C. Тунка «Resonances between Dance and Gnosis» [12]

Большой интерес также представляет Аспирантская школа Ниды, Литва (The Nida Doctora School (NDS), реализующая интенсивную программу для соискателей DA и PhD в области изобрази тельного и перформативного искусства, дизайна, медиа и архитектуры, а также гуманитарных наук. Программа предполагает тесное сотрудничество с выдающимися практиками в соответствующих областях, доклады, дискуссионные группы, презентации докторских исследований (формальные, неформальные, перформативные, экспериментальные и т.д.), рецензирование, групповые и индивидуальные консультации. В 2019 году инициативы NDS проходят на площадках Венецианской биеннале - в Литовском и Исследовательском павильонах [16] и др. Чрезвычайный интерес представляет сам формат исследовательского павильона. Здесь мы наблюдаем «встречное» движение - из академии в мир искусства. Исследовательский павильон - это международный проект, организованный Uniarts Helsink при поддержке the Louise and Göran Ehrnrooth Foundation, а также Aalto University, Valand Academy of Arts at the University of Gothenburg University of Applied Arts Vienna $\boldsymbol{n}$ Interlab Hongik University Seoul. В рамках этого павильона, существующего уже шесть лет (это возобновляемый проект, который уже в третий раз реализуется на Венецианской биеннале), акцент делается на художественном исследовании (artistic research). Цель проекта - привлечь художников и исследователей со всего мира на площадки павильона который мыслится катализатором налаживания сотрудничества в области художественных исследований и генератором «нового мышления» (новой логики взаимодействия художника и академии). Например, нынешний Исследовательский павильон (Исследовательский павильон № 3 ) имеет модульную структуру, состоящую из шести исследовательских ячеек - пространств для параллельных процессов экспонирования, проведения, демонстрации и обсуждения исследований. Один из этих «модулей» носит название «Shelters» ${ }^{1}$ («приюты», «убежища») и посвящён

Проект основан на исследованиях, которые проводились в течение последних трех лет совместно с Исследователь-

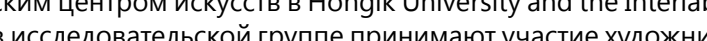
ки, кураторы, архитекторы, инженеры и философы вопросам функционально-ориентированного го родского планирования.

Не отказываясь от специфики «традицион ной» аспирантуры (написание диссертационного исследования), западные аспирантские школ по искусству и дизайну стремятся дополнить ее естественным для креативных индустрий элементом - проектно-практической деятельностью, так называемой «практикой». Таким образом, концептуально важные, весомые выводы и решения обычно имеющие социальное значение, оформляются в конкретные проекты с учётом контекста социоматериального мира и трансформирую этот контекст (в чём выражается практическая значимость диссертационного исследования).

В России же формат практико-ориентированной аспирантуры практически неизвестен, нет ни одной отечественной аспирантской школы по искусству и дизайну, где бы он реализовывался, нет осмысления этого вида исследовательской деятельности в специальной научной литературе. Отечественное образование в данной сфере на сегодняшний день по-прежнему сфокусировано в основном на пролонгации традиционной академической парадигмы. Многие художественные вузы (например, Московский государственный академический художественный институ им. В. И. Сурикова при Российской академии ху дожеств, Санкт-Петербургский государственный академический институт живописи, скульптурь и архитектуры им. И. Е. Репина при Российской академии художеств, факультет искусств МГУ им. М.В.Ломоносова и др.) готовят специалистов ориентированных на работу в рамках академического искусства, и недостаточно внимания уделяют актуальным художественным практикам спецификой которых (в свете модернистских и постмодернистских трансформаций искусства) является осмысление условий производства искусства, а также широкий круг вопросов, связанных с экономическим, политическим и культурным развитем современного общества.

13 декабря 2019 года в Школе дизайна прошёл второй круглый стол, посвящённый проблемам современного образования в области искусства и дизайна в России и в мире. Это была вторая встреча в серии дискуссий, инициированных Аспирантской школой по искусству и дизайну НИУ ВШЭ. В рамках данного круглого стола коллеги из-за рубежа делились собственным опытом. В частности, Эльзе Скьолд, доцент кафедры 
дизайна и устойчивого развития Датской королевской академии искусств (Копенгаген, Дания) представила успешные проекты исследований, реализованные в формате PhD by Practice в Королевской академии изящных искусств Дании (KADK). Среди представленных «кейсов» большой интерес вызывает PhD-исследование Карен Мари Хаслинг (DSKD) «Обучение через материалы. Развитие преподавания материаловедения в области дизайнерского образования» (2015), в котором автор предпринимает попытку ответить на вопрос о том, как может обновлённое понимание материалов в дизайнерском образовании помочь студентам сформировать навык обоснованного выбора материалов, под

Также в рамках круглого стола были озвучень новые образовательные технологии в выступлении Барбары Брауни (Хартфордширский университет, Великобритания), поделившейся опытом успешной реализации подобного рода «симбиотических» проектов, в которых практика и теория способствуют взаимообогащению и дальнейшему развитию исследовательской мысли. В качестве иллюстрации этих идей особый интерес представляет исследование Дэна Гудбрея (диссертация завершена в 2017 году и защищена в Университете Хартфордшира). Исследование Гудбрея посвящено цифровым комиксам и направлено на то, чтобы понять, как ключевые характеристики комиксов влияют на цифровую медиацию. В ходе исследования автор изучал цифровые расширения и замены страницы, гибридизацию видеоигр, проблемы архитектурного пространства и интеграцию в структуру комиксов звуковых, основанных на времени, саундтреков. Так как работа Гудбрея представляет собой конвергенцию теории и практики, то в рамках своих практических исследований он создал серию прототипов и экспериментальных рабо как в физической, так и в цифровой областях. Их можно увидеть на сайте e-merl.com. Также Дэн Гудбрей сделал проект «пространственного комикса», разместив «кадры» из созданного им комикса в архитектурной среде. На основании этого проекта в своём исследовании он показывает, что галереи, практикующие подобный подход (размещение изображений из комикса в конкретном пространстве), опираются на подходы, первоначально появившиеся в цифровых форматах для решения проблем архитектурной медиальности. Исследование Гудбрея позволяет нам уточнит наше понимание комикса как медиума. Анализ этого и других кейсов позволяет утверждать, что в настоящее время в западных академических крувах утверждается новый взгляд на практику как научно значимую деятельность. Так как новое знание получено или частично продемонстрировано «на практике», то и доказательство практической значимости полученных концептуальных выводов также происходит не только в рамках теории, но и в пространстве практических исследований, что способствует их верификации.

\section{Критерии оценки практической значимо}

\section{и проектов: предварительные результаты}

В вопросах, связанных с институционализацией программ практико-ориентированной аспирантуры, наибольшую дискуссию вызывают эффективные критерии оценки собственно проектной части. Отчасти это происходит из-за несовпадения подходов (академическая теория больше склоняется к ОПисательно-аналитическим подходам и методам, тогда как практика - к креативно-деятельностным, нацеленным на решение конкретной проблемы). Наиболее эффективной стратегией представляется совмещение данных подходов с целью актуализации их эффективности. Так, рассуждения о дизайн-мышлении и дизайн-методологии применительно к сфере науки можно найти в трудах многих исследователей. Среди наиболее интересных необходимо назвать Роберта МакКима, художника и инженера, автора книги «Опыты визуального мышления» (1973). Саму концепцию «дизайн-мышления» сформулировал Гербер Саймон в своей книге «Науки об искусственном» (1969) [2]. Найджел Кросс в стать «Дизайнерские способы знать» [1] выявляет уникальные характеристики дизайн-мышления, находя полезным его интеграцию не только в систему образования, но и в более широкий академический контекст. Наконец, глубоким изучением характеристик дизайн-мышления и академического мышления занимался Брайан Лоусон. В эмпирических исследованиях трёхмерного решения проблем, проходивших с использованием двух групп студентов («практики» и «учёные») он обнаружил, что «практики» использовали когнитивные стратегии ориентированные на решение проблемы («синтез»), а «ученые» использовали проблемно-ориентированные стратегии («анализ») [11]. Идея объединить и то и другое в рамках системного подхода на сегодняшний момент звучит всё чаще причём не только в среде дизайнеров/художни- ков или в академической среде, но и в области бизнеса. Например, существует образовательно-исследовательский центр DesignLondon (Великобритания), объединивший в себе три наиболее влиятельные в своей области школы в Британии дизайн-отделение Royal College of Art, инженерный факультет Imperial College $и$ бизнес-направление из Imperial College Business School. Среди других значимых проектов в данной области Компания «RED» (иничиатива по трансформации публичного сектора и сферы государственных услуг (Design Council, Британский Совет по Дизайну; цель - «внедрение дизайн-инноваций с целью повышения уровня и качества жизни», «внедрение дизайна в социальную и экономическую сферу для решения критических вопросов» [8], а также международная консалтинговая организация в области дизайна «IDEO». Кроме этого, помимо дизайн-проектов, связанных с проблемами общества и экономики, существуют аналогичные инициативы в сфере искусства, например, область «социального искусства», также связанные с инкорпорированием художника в социальную и экономическую сферу с целью её трансформации.

Представляется логичным что проектная составляющая практико-ориентированного аспирантского проекта должна быть вписана в логику соответствующего проблемного поля, и образовательные институции обязаны представить вари анты решения поставленных проблем. При этом проектная составляющая должна существ в рамках крепкой теоретической структуры высокого академического уровня. В качестве одного из примеров существующей «кодификации» критериев оценивания подобных исследований можно рпомянуть совместную аспирантскую програм мy PhDArts (результат коллаборации Академии креативных и перформативных искусств Лейденского университета и Королевской академией искусств в Гааге), о которой речь шла выше. На сайте программы приведены основные понятия, сформулированы критерии оценивания исследования, основанного на практике (practice-based research), а также дано его определение: «Исследование, основанное на практике, применительно к творческим специальностям понимается как исследование, проводимое в области художественных практик и методов дизайна и с их применением (например, в таких направлениях, как изобразительное искусство, аудиовизуальное искусство, дизайн, дизайн интерьера, смешанные формы и междисциплинарные области); при этом практическая деятельность и аналитическая работа самого исследователя неразрывно связан с темой исследования, его процессом и результатами. Если соискатель претендует на докторскую степень, он должен продемонстрироват высокий уровень творческого мастерства, ори гинальность и навыки, чтобы его исследование можно было оценить как важный и новаторский вклад в науку, философию искусства и творческую практику» [13].

Подобные «кодификации» требований и критериев оценивания текстовой составляющей и проектной деятельности существуют в рамках всех программ практико-ориентированных аспирантур. Различия могут быть в числе экспертов, привлекаемых для оценки проекта, в требования к объёму текста, к документации, сопровождающей проект и пр. В 2006 году Линда Кэнди выступила с докладом и написала статью-гайд «Practice Based Research: A Guide» [6, 7], в которой предприняла попытку отразить специфику данного вопроса; в дальнейшем этот «гайд» получил развитие в её статье 2018 года «Practice-based research in the creative arts: Foundations and Futures from the Front Line» [5, p. 63-69], которую она написала совместно с Эрнестом Эдмондсоном. В статье даны описания большого количества «кейсов»; анали зируя один из них, Кэнди и Эдмондсон резюмируют: «Ключевые результаты нашли отражение в произведениях искусства, которые способствовали формированию у вовлечённых в процес зрителей новых идей. Необходимо было проде монстрировать, что перед нами конкретный кейс поэтому были представлены не только результаты исследования в письменном виде и в форме различных артефактов, документирующих его процесс, но и общая картина реакций участни ков. Поэтому удалось достаточно традиционным способом показать обоснованность выдвинутого тезиса. Это пример исследования, основанного на практике; главное в нём - творческая составляющая, но в то же время приведены выводы подкреплённые доказательствами» [5, р. 63-69].

Наконец, в качестве действующей «рабочей модели» выступают критерии оценки и аттестации исследований в Королевской академии изящных искусств Дании (KADK) 2 :

Так как формулировки периодически дорабатываются версия на сайте может не во всём совпада
представленной в тексте настоящей статьи. 
«Ясность: Критерий относится к эстетической составляющей работы. Необходимо, чтобы был возможность оценить, насколько чётко работа отделена от контекста и условий создания. В соответствии с этим критерием обсуждается эстетический эффект работы и выбранный автором художественный язык (художественный уровень),

Интенсивность: Критерий относится к технической составляющей работы. Важно понять, что во внешнем виде произведения содержится эффект, и каким образом связь между элементами определяет интенсивность воздействия. В соответствии с этим критерием оценивается то, как свойства материала, его функции и концепции сочетаются в новых контекстах (технический уровень).

Глубина: Критерий относится к смысловой составляющей работы. Важно определить глубину отношения произведения к смыслообразованию в культуре и обществе. В соответствии с этим критерием работа соотносится с классом работ, которые продемонстрировали актуальность развития темы, и обсуждается её вклад (контекстуальный / теоретический уровень).

Экспертная оценка: квалифицированный практик + квалифицированный исследователь в данной области» [17].

Таким образом, на основании анализа программ практико-ориентированных аспирантур среди основных критериев оценивания практической составляющей диссертационного проекта можно выделить следующие:

- обоснование актуальности проекта (описание границ проблемного поля, постановка проблемы, формулировка цели; предложенный проек решает поставленные проблемы или предлагает варианты решений поставленных проблем?)

- оригинальность и новизна (проект должен быть оригинальным и не иметь полных аналогов),

- презентация проекта; оценивает эксперт/ эксперты (ведущие специалисты в соответствующей проблемной области);

- владение методологией, в том числе проектной (напр., artistic research, practice as research дизайн-методология); оценивает эксперт/эксперть (ведущие специалисты в соответствующей проблемной области);

- наличие квалифицированной команды, ре ализующей проект, логики поэтапного планирования, иных условий, способствующих успешной реализации, достигнутые результаты реализации (например, наличие артефактов (произведений) факт состоявшейся выставки, перформанса и пр,

- социальная значимость проекта (например, наличие высокой оценки со стороны экспертного сообщества, отзывов в прессе и др.); возможна экспертная оценка ведущих специалистов в данной области; может учитываться инвестиционная привлекательность проекта.

\section{Заключение}

В настоящий момент наблюдается процесс “сближения» академического сообщества и сообщества «практиков» - художников и дизайнеров, поскольку, с одной стороны, учёные заинтересованы во внедрении своих разработок в практику, а с другой стороны, художники и дизайнеры нуждаются в дифференциации и концептуализа ции своего предметного поля. Это связано с тем, что процессы в производстве, дизайне, отчасти и в искусстве стали меняться, происходит переход от создания артефактов / корпуса артефактов к проектированию неосязаемых вещей-это может быть услуга, сервис, стратегия, «атмосфера» и т.д. Подобная ситуация привела к тому, что в пространстве академических образовательных программ начали появляться новые форматы взаимодействия «теории и практики», причём и на уровне высшей школы - речь идёт о формате практико-ориентированной аспирантуры («PhD by Practice», «Art PhD», «practice-based research», «practice-led research» и т.д.). В рамках данной статьи мы предприняли попытку отразить специфику данного формата, обратились к опыту зарубежных стран, где данный формат набирает всё большую популярность, затронули проблемы (прежде всео методологические), связанные с интеграцией данного формата в пространство академических знаний, отрефлексировали дискуссионность такого понятия, как "Practice as Research", и пути разви тия этого образовательного формата. До сих пор идёт интенсивная дискуссия относительно статуса «практики» как образовательного формата. Представляется, что на сегодняшний день поиск новых форм взаимодействия академического сообще ства и сообщества «практиков», и «доработка» уже существующих форматов является актуальной задачей, решение которой будет способствовать развитию социально-культурных инициатив и формированию креативного сообщества с доминантой художественного делания. Обобщая сказанное, можно с уверенностью сказать, что аспирантские программы уровня PhD, обсуждаемые в Аспирантской школе по искусству и дизайну НИУ ВШЭ, являются альтернативной формой обучения, в процессе которого обучающиеся могут не только расширить теоретические знания проводить междисциплинарные исследования, но и репрезентировать проектные формы, демонстрируя навыки и компетенции полученные в сфере современного дизайна и искусства. Важной составляющей являются и практические ис

БИБЛИОГРАФИЯ

1. Кросс Н. Дизайнерские способы знать 10. Interview between the JAWS editorial team and D («Designerly ways of knowing»). - 1982 [Сетевой ресурc]. - URL: http://larossa.co/cross_1982 designerlywaysofknowing.pdf / (дата обращения: 05.07.2021).

2. Саймон Г. Науки об искусственном.- М.: Мир, 1969 Art \& Education / PhD in Practice, Academy of Fin Arts Vienna [Cетевой pecypc].- URL. https://www. artandeducationnet/an pecypcl.practice-academy-of-fine-arts-vienna/ (дата обраще-
ния: 05.07.2021).

4. Arts and Hymanities Reseach Concil [Сетевой peArts and Hymanities Reseach Concil Сетевой pe-
cypc].—URL: https://ahrc.ukri.org/ (дата обращения: cypc].—URL:

5. Candy L., Edmonds E. Practice-based research in the creative arts: Foundations and Futures from the Fron Line // LEONARDO. - Vol. 51.- No. 1. - 2018

6. Candy L. Theory and Practice in Creative Practitioner Research. Unpublished paper based on Keynote Talk to DESIRE2011 conference Eindhoven NL. [Сетевой pecypc]. - URL: https://www.academia.edu/10331703/ Theory_and_Practice_in_Creative_Practitione Research/ (дата обращения: 05.07.2021).

7. Candy L. Practice Based Research: A Guide. CCS Report: 2006-V1.0 November [Сетевой ресурс].-URL: https://www.researchgate.net/publication/257944497/ (дата обращения: 05.07.2021)

8. Design Council [Online]. - URL: https://www. designcouncil.org.uk/ (дата обращения: 05.07.2021).

. Epstein R. (2005). Generativity theory and creativity. In M. A. Runco \& R. S. Albert (Eds.), Theories of creativity (Rev. ed.). Cresskill, NJ: Hampton Press, 2005. следования, которые позволят актуализировать подход к практике как исследованию и инкорпорировать методологический инструментарий в репрезентативные формы апробации проектов. Практико-ориентированные аспирантские программы для российской системы образоватребующий осмысления и выбора собственной образовательной стратегии связанной со спецификой многоуровнего и многопрофильного об разования в России. ния представляют собой инновационный формат 